\title{
Influences of Boundary Space Amelioration on Residents' Key Perceptions in Communities
}

\author{
Heng Zhang, Yu-Hao Ou, Yu-Min Chang
}

\author{
Department of Architecture, \\ National Cheng Kung University, Taiwan \\ changlin@mail.ncku.edu.tw, ddp982811@gmail.com, c25678822@gmail.com
}

Tel: +886-917-798-255

\begin{abstract}
Boundary space amelioration (BSA) aims to eliminate barriers between two sites and activate the grey residual space in-between. School campus in Taiwan is often surrounded by walls, which blocks its connection to communities and often creates security concerns. School campus has become the most popular target for BSA, which tries to turn it into a functional and aesthetic space. This study intends to explore the influences of campus BSA within a community, especially its relationships with neighborhood safety, perceived change and place attachment. The result shows that the improvement of boundary environment has a significant influence on all three perceptions.
\end{abstract}

Keywords: Environmental design; Neighborhood safety; Perceived change; Place attachment

eISSN 2398-4279 @ 2019. The Authors. Published for AMER ABRA cE-Bs by e-International Publishing House, Ltd., UK. This is an open access article under the CC BY-NC-ND license (http://creativecommons.org/licenses/bync-nd/4.0/). Peer-review under responsibility of AMER (Association of Malaysian Environment-Behaviour Researchers), ABRA (Association of Behavioural Researchers on Asians) and CE-Bs (Centre for EnvironmentBehaviour Studies), Faculty of Architecture, Planning \& Surveying, Universiti Teknologi MARA, Malaysia.

DOI: https://doi.org/10.21834/ajqol.v4i16.193 


\subsection{Introduction}

As society changes, the school campus is no longer an enclosed learning environment, but a popular field of activity. The primary school campus, in particular, has a close connection to community life. The space that lies between the campus and the community is not merely a transition space, but also a place where the two interact and guard against each other. In the past, the principle of site planning in Taiwan was to enclose individual sites with walls. Planning and design were conducted in isolation within the walls. This planning approach often results in grey residual space between two adjacent sites, which is neither functional nor safe. The purpose of "Boundary space amelioration" is to remove the walls and activate the grey residual space between the two sites to turn it into a functional and aesthetic space. Campus boundary space makes up the transition space between the community and the school. However, through environmental transformation, including the use of open walls as well as greening and beautifying the walls could blur this boundary. Therefore, this study intends to explore the impact of campus boundary amelioration within a community, especially its relationships with neighborhood safety, perceived change and place attachment.

\subsection{Literature Review}

\subsection{Boundary space amelioration (BSA)}

The difference between boundary space amelioration (BSA) and general space amelioration is that BSA only ameliorates the adjacent space between two sites, and there is no need to rectify the original spatial structure. This type of space amelioration method reduces cost (Dober, 2000), and the amelioration efforts tend to focus on landscape and traffic circulation.

The amelioration of boundary space mainly targets landscape renovation that improves visual qualities. The visual elements include manmade elements and ecological resources (Daniel \& Vining, 1983; Saeidi, Mohammadzadeh, Salmanmahiny, \& Mirkarimi, 2017). In addition, a school campus also serves transportation, education, communication, and recreational functions, and it should integrate ecological, cultural and local characteristics with individuality (Ruihai \& Dinghai, 2017). Outdoor space, street furniture, manmade objects, plants, sidewalks and buildings (Lynch \& Hack, 1984; Zhang \&Lin, 2011) are regarded as an environmental stimulus for the residents. In terms of campus landscape, lawns, trees, colors, planting density, sculpture, ponds, and fountains, etc. will affect people's perception (Lau, Gou, \& Liu, 2014). Elements in the public space that provide comforts include leisure space, street furniture, proper sidewalk scale, planting, shading, and manmade objects (Mehta, 2014; Sullivan, Kuo, \& Depooter, 2004).

According to the above-referenced literature and characteristics of the subject site, this study divides the spatial amelioration factors into six elements: "directional system and public art", "planting", "outdoor furniture", "sidewalk", "lighting facilities" and "fence or hedge".

\subsection{Neighborhood safety}

Safety is the basic needs of human beings. On the psychological aspect, it has the expected 
effect on personality development. And psychological safety helps to make the needs of personal trust and communication be satisfied, creates a sense of belonging to the environment, and promote mental health (Bordovskaia \& Baeva, 2015). Perception of safety will affect the walking ability and physical activity (Abdullah, Marzbali, Ramayah, Bahauddin, \& Tilaki, 2016). Safety is the most important factor to explain walking behavior. If people feel the fear, they won't go out to use local facilities, participate in activities, or interact with strangers on the street (Pikora, Giles-Corti, Bull, Jamrozik, \& Donovan, 2003).

According to the literature, we know that walking activity is an act of feeling safe to the place. Therefore, this study defines that neighborhood safety will base on the feeling of pedestrian and environmental safety around the campus. we divided neighborhood safety into two aspects: "criminal security" and "traffic safety".

\subsection{Perceived change}

Perception is the psychological process based on past experiences that people combine the information obtained from external environmental stimuli to evaluate and interpret (Grahn \& Stigsdotter, 2010; Lindsay \& Norman, 2013). Jessor and Jessor (1973) proposed that environmental perception is temporal, and the environmental attributes are perceived to have different development feelings over time or at different stages of life. The perceived change was first mentioned by Sell and Zube (1986), the study explores the responses of people's perceived to urban change and proposes three dimensions to assess how people feel when a place changes over time: "Scope, speed, and control." These three dimensions effectively solve the characteristics of perceived change, the value is that it will change over time and the city change into positive (enhance, upgrade) or negative (threat, stress) (Devine-Wright, 2009; von Wirth, Grêt-Regamey, Moser, \& Stauffacher, 2016).

In this study, we use the Perceived Urban Change (PUC-t) proposed by von Wirth et al. (2016), to divide perceived change into two factors: "positive development" and "environmental change".

\subsection{Place attachment}

Place attachment is defined as the emotional connection to a specific environment. This emotional connection refers to the emotional devotion in a certain place, or the personal recognition of a specific environment (Scannell \& Gifford, 2017). It will conduce to strong attachment in a fixed boundary over time in the place theory proposed by Yi-Fu Tuan (1975). People will have a strong emotional impact on fixed areas in process of time, so residents have more feeling of attachment to the community. If people have an attachment to their residence, they will be friendlier with their neighbors and trust others (Kasarda \& Janowitz, 1974; Lewicka, 2013).

Place attachment research includes place emotional attachment and functional attachment. Emotional attachment is often referred to as place identity, while functional attachments are called place dependence. Many studies often use these two aspects to describe place attachment (Anton \& Lawrence, 2016; Lin \& Lockwood, 2014; Moore \& Graefe, 1994). This study is based on the literature mentioned above, and the place 
attachment is divided into two aspects: "place identity" and "place dependence".

\subsection{Relationships among BSA, perceived change, neighborhood safety, and place attachment}

There is a significant relationship between the architectural environment and people's sense of safety (Wood et al., 2008; Omar, Omar, \& Yusoff, 2016). In safe and densely populated areas, residents will be more likely to choose walking as the main means of transportation (Hong \& Chen, 2014). Environmental risk factors such as road design to be a negative influence on pedestrian safety and these risk factors increase the possibility of death and injury (Clifton \& Kreamer-Fults, 2007; LaScala, Johnson, \& Gruenewald, 2001). Therefore, planners need to understand not only the interrelationship between these factors, but also assess the risk of building environment during the planning, implementation and evaluation process. People who live communities with good transportation and pedestrian access tend to construe their communities as being safe (Hong \& Chen, 2014), thus demonstrating a potential indirect link between safety and the architectural environment (Loukaitou-Sideris, 2006; Wood et al., 2008).

The perceived change has to do with how humans receive information and stimulus from the physical environment through their five senses, and the mental process they go through to formulate evaluation, assessment, and interpretation based on past experience (Coeterier, 1987; Rapoport, 2016). Therefore, environmental transformation poses the most direct impact on perceived change. Based on the theory of evolution, it is human nature to feel attached to the environment (Riley, 1992). It is evident from the landscape assessment study that the types of the landscape may vary according to group preferences (Herzog, Herbert, Kaplan, \& Crooks, 2000; Strumse, 1996; Yu, 1995). Changes in the landscape or natural environment as a result of human activities also trigger different preferences among different groups, and people grow attached to specific places for various reasons (Low \& Altman, 1992; Toruńczyk - Ruiz \& Lewicka, 2016).

Environmental changes are related to the changes in residents' place attachment. Among specific groups, such changes may affect people's sense of identity and generate strong place attachment. On the other hand, place attachment may also affect how people perceive changes in urban areas (Bonaiuto, Carrus, Martorella, \& Bonnes, 2002; Matilainen, PohjaMykrä, Lähdesmäki, \& Kurki, 2017). Therefore, before comprehending the influence of residents' attitudes and behavioral intentions, it is necessary to have a basic understanding of the relationship between characteristics of place changes and residents' attachment (von Wirth et al., 2016). Based on the above theory, it can be hypothesized that the planning and design of architectural environment have an impact on neighborhood security and it will affect residents' psychological state, thus affecting pedestrian behavior and attachment, as well as perception toward environmental changes. Therefore, this study hypothesizes that boundary amelioration has an impact on perceived change, neighborhood safety, and place attachment. 


\subsection{Methodology}

Based on the literature review, the relationships among boundary space amelioration, perceived change, neighborhood safety, and place attachment could be identified. This study aims to explore the impact of BSA and the relationships among perceived change, neighborhood safety and place attachment. Figure 1 shows the research framework, and multiple regression analysis was used to analyze the interrelationship among the four constructs.

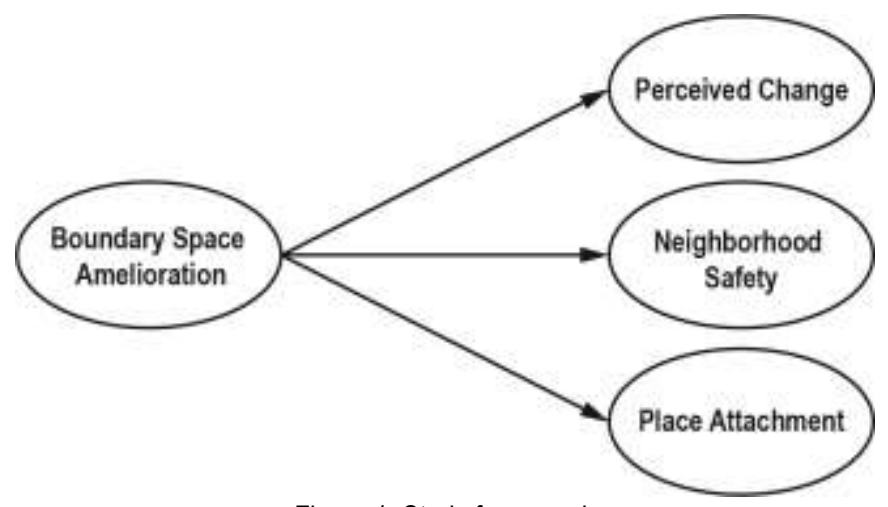

Figure 1: Study framework

\subsection{Study site}

This study aims to explore the influences of boundary space amelioration on the resident, and school campus in Taiwan is often surrounded by walls, which blocks its connection to communities and often creates security concerns. School campus has become the most popular target for BSA, which tries to turn it into a functional and aesthetic space. Limited by time and manpower, this study has chosen three campuses of BSA cases in the Eastern District of Tainan as study sites. The scale of these cases and the degree of amelioration vary. They are Chong-Syue, Sheng-Li, and Da-Tong elementary schools.

\subsection{Population and Sampling}

The sample population of this study is residents within the 200-meter radius of the school campus. Based on the census information from Tainan City Government and the stratifiedquota sampling method, the sample size should be 369 . The actual number of questionnaires distributed for each site was determined according to the percentage of the of each site against the combined population. A total of 431 questionnaires were collected and 392 are valid. 
Heng, Z., et.al. / Asian Journal of Quality of Life (AjQLL), 4(16) May/Aug 2019 (pp.16-32)

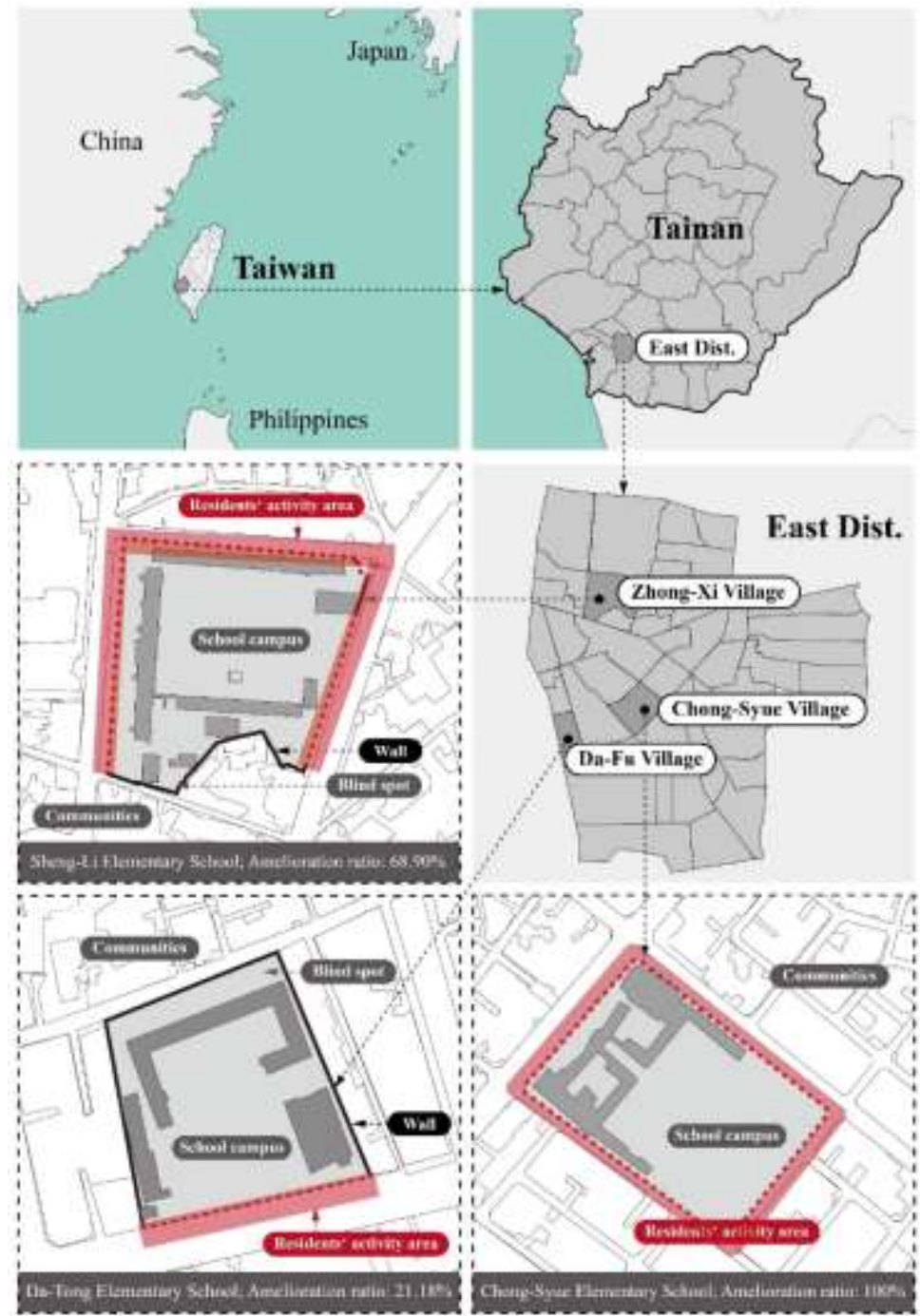

Fig. 2: Study sites

Table 1. The population of each study site

\begin{tabular}{|c|c|c|c|c|c|}
\hline Elementary School & $\mathrm{N}$ & $\%$ & Questionnaire & Valid & Invalid \\
\hline Sheng-Li elementary school & 3,376 & $37.2 \%$ & 155 & 138 & 17 \\
\hline Chong-Syue elementary school & 3,766 & $41.5 \%$ & 175 & 161 & 14 \\
\hline
\end{tabular}


Heng, Z., et.al. / Asian Journal of Quality of Life (AjQoL), 4(16) May/Aug 2019 (pp.16-32)

\begin{tabular}{lccccc}
\hline Da-Tong elementary school & 1,935 & $21.3 \%$ & 101 & 93 & 8 \\
\hline \hline Total & 9,077 & $100 \%$ & 431 & 392 & 39 \\
\hline
\end{tabular}

\subsection{Measurement Scale}

Based on the literature review, the study proposes two sub-dimensions as the scale for perceived change. The sub-dimensions include "positive development" and "environmental change" (von Wirth, Grêt-Regamey, Moser, \& Stauffacher, 2016); the two sub-dimensions for neighborhood safety are "security against crime" and "traffic safety" (Saelens, Sallis, Black, \& Chen, 2003); the sub-dimensions for place attachment are "place identity" and "place dependence" (Anton \& Lawrence, 2016; Moore \& Graefe, 1994).

\subsection{Study method}

\subsubsection{Exploratory Factor Analysis}

The purpose of using factor analysis is to simplify data. In this study, factors with the same characteristics as BSA, perceived change, neighborhood safety, and place attachment were extracted. During the analysis, the KMO sampling suitability test and Bartlett spherical test were conducted to determine whether the data is suitable for factor analysis. In addition, Cronbach's alpha is used to test the internal consistency of the latent dimensions (Hair, 2010).

\subsubsection{Multiple Regression Analysis}

Multiple regression analysis was conducted to explore the relationships between independent and dependent variables. Using the linear relationship between them, the prediction could be made to infer which independent variables affect the dependent variable. In this study, the multiple regression analysis is used to explore the relationships among BSA, perceived change, neighborhood safety, and place attachment.

\subsection{Results and discussion}

\subsection{Factors of boundary space amelioration (BSA)}

A01 to A29 are items included in BSA factors. First, reliability analysis is conducted, followed by factor analysis to consolidate and name the factors. Referencing past literature and the content under each factor, the six factors are named "directional system and public art", "planting", "outdoor furniture", "sidewalk", "lighting facilities" and "fence or hedge".

Table 2. Boundary space amelioration factor analysis 


\begin{tabular}{|c|c|c|c|c|c|c|c|}
\hline A18 & The design of directional signs is good. & .748 & .147 & .164 & .192 & .332 & .097 \\
\hline A17 & The content of directional signs is easy to read. & .721 & .148 & .201 & .172 & .314 & -.050 \\
\hline A19 & The directional signs are functional. & .705 & .226 & .241 & .175 & .343 & .097 \\
\hline A21 & The public art is approachable. & .674 & .298 & .216 & .201 & -.044 & .208 \\
\hline A22 & The placement of public art is appropriate. & .664 & .257 & .265 & .224 & .009 & .238 \\
\hline A20 & Each public art is distinct. & .632 & .283 & .148 & .164 & .031 & .371 \\
\hline A23 & $\begin{array}{l}\text { The electricity poles or power distribution boxes } \\
\text { have been beautified. }\end{array}$ & .523 & .210 & .092 & .060 & .189 & .258 \\
\hline \multicolumn{8}{|c|}{ Planting (Factor 2) } \\
\hline A27 & Plants make me feel relaxed. & .239 & .811 & .115 & .209 & .147 & .148 \\
\hline A26 & $\begin{array}{l}\text { One can see the green environment during the } \\
\text { walk. . }\end{array}$ & .237 & .784 & .163 & .180 & .142 & .146 \\
\hline A29 & There is a variety of plants. & .158 & .742 & .194 & .146 & .227 & .065 \\
\hline A25 & The landscape design is unique. & .267 & .737 & .131 & .164 & .203 & .229 \\
\hline A28 & The plants are pleasing to the eye. & .214 & .736 & .110 & .124 & .171 & .152 \\
\hline \multicolumn{8}{|c|}{ Outdoor furniture (Factor 3 ) } \\
\hline A04 & The outdoor furniture is functional. & .141 & .152 & .830 & .084 & .071 & .185 \\
\hline A03 & $\begin{array}{l}\text { The outdoor furniture blends with the } \\
\text { surrounding. }\end{array}$ & .194 & .202 & .790 & .090 & .167 & .081 \\
\hline A01 & The location of outdoor furniture is appropriate. & .149 & .170 & .771 & .190 & .091 & .102 \\
\hline A05 & The outdoor furniture promotes interaction. & .175 & .130 & .770 & .151 & .040 & .120 \\
\hline $\mathrm{A} 02$ & The amount of outdoor furniture is adequate. & .166 & -.011 & .703 & .187 & .123 & .149 \\
\hline \multicolumn{8}{|c|}{ Sidewalk (Factor 4) } \\
\hline A06 & The sidewalk scale is appropriate. & .130 & .210 & .219 & .756 & .138 & .153 \\
\hline A08 & The sidewalks have good walkability. & .181 & .203 & .199 & .755 & .185 & .196 \\
\hline A07 & The sidewalks are barrier free. & .306 & .174 & .192 & .700 & .060 & .073 \\
\hline A09 & The pavement design is distinctive. & .279 & .237 & .179 & .536 & .218 & .344 \\
\hline \multicolumn{8}{|c|}{ Lighting facilities (Factor 5 ) } \\
\hline A14 & The lighting facilities provide adequate lighting. & .160 & .206 & .123 & .101 & .818 & .136 \\
\hline A15 & The lighting is soft. & .205 & .269 & .149 & .121 & .794 & .174 \\
\hline A16 & $\begin{array}{l}\text { The lighting facilities blend with the surrounding } \\
\text { environment. }\end{array}$ & .272 & .241 & .134 & .228 & .723 & .116 \\
\hline \multicolumn{8}{|c|}{ Fence or hedge (Factor 6 ) } \\
\hline A12 & The fence or hedge serves as a physical buffer. & .017 & .064 & .140 & .123 & .101 & .688 \\
\hline A11 & The fence or hedge is artistic. & .302 & .230 & .174 & .127 & .119 & .675 \\
\hline A13 & The fence or hedge are well designed. & .361 & .211 & .150 & .159 & .168 & .650 \\
\hline A10 & The fence or hedge is visually penetrable. & .203 & .270 & .329 & .243 & .094 & .465 \\
\hline
\end{tabular}


Heng, Z., et.al. / Asian Journal of Quality of Life (AjQoL), 4(16) May/Aug 2019 (pp.16-32)

\begin{tabular}{lllllll}
\hline Number of Item & 7 & 5 & 5 & 4 & 3 & 4 \\
Eigenvalue & 11.975 & 2.180 & 1.468 & 1.415 & 1.223 & 1.084 \\
Cronbach's a & 0.898 & 0.910 & 0.886 & 0.834 & 0.877 & 0.754 \\
Explained Variation (\%) & 14.868 & 13.958 & 13.458 & 9.206 & 9.198 & 8.404 \\
Total Explained Variation (\%) & 14.868 & 28.826 & 42.284 & 51.490 & 60.687 & 69.092 \\
\hline
\end{tabular}

\subsection{The total effect of BSA on perceived change, neighborhood safety, and place attachment}

The results show that boundary amelioration has a significant effect on neighborhood safety, perceived change and place attachment, and all with a large effect size (Cohen, 1992). Ranging from large to small effect sizes are perception of environmental change, neighborhood safety and place attachment. Overall, planting has the greatest impact on perceived change, neighborhood safety and place attachment.

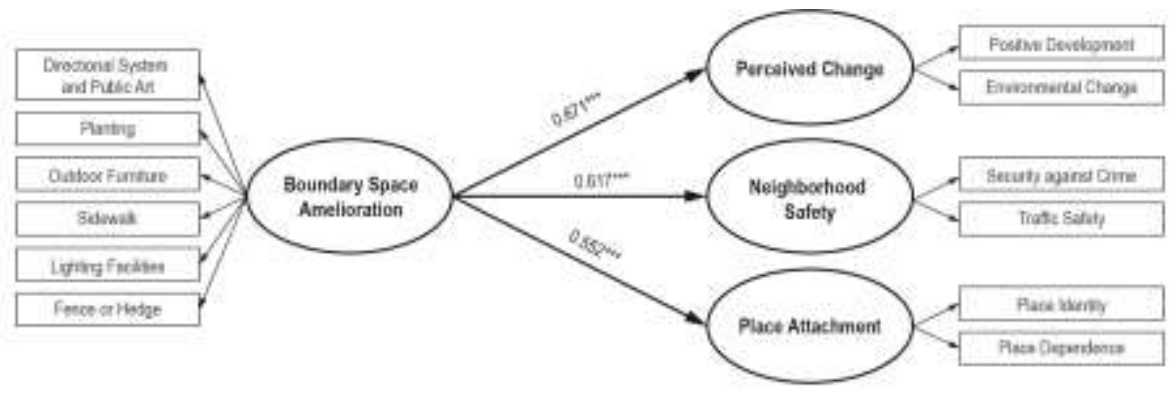

Fig. 3: The total effect of BSA on perceived change, neighborhood safety, and place attachment

\subsection{The relationship between BSA elements and perceived change}

This study further explores the effect size of BSA factors on each dimension. The results are shown in Table 3. Among the BSA factors affecting perceived change, "planting", "outdoor furniture", "directional system and public art", "fence or hedge" and "lighting facilities" pose significant effects. Among them, "planting" is the most influential. The effect of planting reaches a medium size (0.36), and the effect size of other factors are small $(0.1 \sim 0.16)$.

There are two factors in perceived change: positive development and environmental change. In the effect of BSA factors on positive development, only "planting", "outdoor furniture", "directional system and public art" and "fence or hedge" have significant effects. Among the factors, "planting" is the most influential (0.39). Therefore, the most effective way to enhance residents' perception of "positive development" is to strengthen planting.

In the effect of BSA factors on environmental change, only "planting", "directional system and public art", "outdoor furniture" and "lighting facilities" have a significant effect on positive development. Among them, "planting" has the most significant influence (0.27). To factors of perceived change, fence or hedge contributes to positive development, and lighting facilities 
affect environmental change. To the perception of environmental, sidewalk improvement is the only item that does not affect residents' perception.

Table 3. Perceived change affected by BSA factors, in which perceived change and its' factors regressed separately by six boundary amelioration factors.

\begin{tabular}{|c|c|c|c|c|}
\hline Dependent variable & $\begin{array}{l}\text { Independent variable } \\
\text { BSA elements }\end{array}$ & $\begin{array}{l}\text { Standardized } \\
\text { Coefficients } \\
\text { Beta }\end{array}$ & Sig. & VIF \\
\hline \multirow{6}{*}{ Perceived change } & Planting & .355 & .000 & 1.954 \\
\hline & Outdoor furniture & 161 & .000 & 1.511 \\
\hline & Directional system and public art & 129 & .024 & 2.337 \\
\hline & Fence or hedge & 106 & .037 & 1.880 \\
\hline & Lighting facilities & .099 & .037 & 1.640 \\
\hline & \multicolumn{2}{|l|}{ adjusted $R^{2}=0.463$} & \multicolumn{2}{|l|}{$\mathrm{P}=0.037$} \\
\hline
\end{tabular}

Factors of perceived change

\begin{tabular}{lllll} 
& Planting & .389 & .000 & 1.815 \\
& Outdoor furniture & .157 & .001 & 1.505 \\
Positive development & Directional system and public art & .133 & .019 & 2.175 \\
& Fence or hedge & .114 & .030 & 1.874 \\
& adjusted $\mathrm{R}^{2}=0.427$ & & $\mathrm{P}=0.030$ & \\
& Planting & .267 & .000 & 1.860 \\
& Directional system and public art & .154 & .013 & 2.123 \\
Environmental change & Outdoor furniture & .151 & .003 & 1.426 \\
& Lighting facilities & .109 & .046 & 1.634 \\
& adjusted $\mathrm{R}^{2}=0.297$ & & \multicolumn{2}{c}{$\mathrm{P}=0.046$} \\
\end{tabular}

The BSA factors have positive effects on perceived change. Planting is an important influence on visual preference and an important perceived factor, which is consistent with previous studies (Ode, Fry, Tveit, Messager, \& Miller, 2009; Purcell \& Lamb, 1998). In directional system and public art, as well as fence or hedge, well-designed artworks can inspire people and influence their perception (Denes, 1993). Therefore, artistic fences or artworks created with collaborate efforts from students improve people's perception of change.

\subsection{The relationship between BSA factors and neighborhood safety}

In the effect of BSA factors on neighborhood safety, "planting", "lighting facilities", "sidewalk", "outdoor furniture" and "fence or hedge" pose significant effects. Among them, "planting" is the most significant.

There are two factors in neighborhood safety: security against crime and traffic safety. In 
the effect of BSA factors on security against crime, only "fence or hedge", "directional system and public art" and "planting" have significant effects. The most influential is " fence or hedge". Prior to the BSA project, the fence and hedge create blind spots that became breeding ground for crimes. After the projects, the blind spots are eliminated, hence improving the sense of security against crime.

In the effect on traffic safety, only "planting", "lighting facilities", "sidewalk" and "outdoor furniture" have significant effects. The most influential is "planting". It is important to note that lighting facilities do not help improve security against crime. Instead, this factor is helpful for traffic safety.

Table 4. Neighborhood safety affected by BSA factors, in which neighborhood safety and its' factors regressed separately by six BSA factors.

$\begin{array}{lllll}\text { Dependent variable } & \text { Independent variable } & \begin{array}{l}\text { Standardized } \\ \text { Coefficients } \\ \text { Beta }\end{array} & \text { Sig. } & \text { VIF } \\ & \text { BSA elements } & .215 & .000 & 1.883 \\ & \text { Planting } & .171 & .001 & 1.575 \\ & \text { Lighting facilities } & .149 & .008 & 1.978 \\ \text { Neighborhood safety } & \text { Sidewalk } & .135 & .006 & 1.522 \\ & \text { Outdoor furniture } & .121 & .028 & 1.861 \\ & \text { Fence or hedge } & & \mathrm{P}=0.028 \\ \text { Factors of neighborhood safety } & \text { adjusted } \mathrm{R}^{2}=0.374 & & & \\ & & .208 & .000 & 1.764 \\ & \text { Fence or hedge } & .195 & .002 & 2.030 \\ \text { Security against crime } & \text { Directional system and public art } & .173 & .004 & 1.805 \\ & \text { Planting } & & \mathrm{P}=0.004 & \\ & \text { adjusted } \mathrm{R}^{2}=0.238 & .231 & .000 & 1.766 \\ & \text { Planting } & .207 & .000 & 1.562 \\ \text { Traffic safety } & \text { Lighting facilities } & .169 & .002 & 1.814 \\ & \text { Sidewalk } & .160 & .001 & 1.436\end{array}$

On the impact of $B$ factors on neighborhood safety, when planting, lighting facilities, sidewalk, outdoor furniture, and other design elements are well planned, they positively affect the safety of a neighborhood and enhances traffic safety. In terms of planting, it has been verified that roadside vegetation has a positive psychological impact on drivers. It reduces their pressure and frustration when driving and reduces their driving speed as well as the risk of collision (Van Treese II, Koeser, Fitzpatrick, Olexa, \& Allen, 2017; Wolf, 2003). Lighting facilities will increase the visibility for both pedestrians and drivers and improve traffic safety. 
The design and maintenance of pedestrian walkways and outdoor furniture also affect pedestrian safety (Clifton and Kreamer-Fults, 2007). Fence or hedge, which defines the boundary, can protect the personal and property safety. The fence and hedge are lowered after the BSA project, which minimizes the blind spots, increase visibility, which greatly improves security against crime.

\subsection{The relationship between BSA factors and place attachment}

In the effect of BSA factors on place attachment, only " planting", "fence or hedge" and "outdoor furniture" have significant effects on place attachment. Among them, the most influential is " planting" (0.39). The other three design factors have no influence on place attachment.

There are two factors in place attachment: place identity and place dependence. The ranking of the effects of design factors on the two place attachment factors is the same. The most significant is planting. Therefore, the most effective way to increase place attachment is to improve the design of planting.

Table 5. Place attachment affected by BSA factors, in which place attachment and its' factors regressed separately by six BSA factors.

$\begin{array}{lllll}\text { Dependent variable } & \text { Independent variable } & \begin{array}{l}\text { Standardized } \\ \text { Coefficients } \\ \text { Beta }\end{array} & \text { Sig. } & \text { VIF } \\ & \text { BSA elements } & .394 & .000 & 1.515 \\ & \text { Planting } & .155 & .004 & 1.669 \\ \text { Place attachment } & \text { Fence or hedge } & .125 & .012 & 1.405 \\ & \text { Outdoor furniture } & & \mathrm{P}=0.037 \\ \text { Factors of place attachment } & \text { adjusted } \mathrm{R}^{2}=0.463 & & & \\ & & & & \\ & \text { Planting } & .388 & .000 & 1.515 \\ \text { Place identity } & \text { Fence or hedge } & .131 & .018 & 1.669 \\ & \text { Outdoor furniture } & .120 & .018 & 1.405 \\ & \text { adjusted } \mathrm{R}^{2}=0.290 & & \mathrm{P}=0.018 \\ \text { Place dependence } & \text { Planting } & .372 & .000 & 1.515 \\ & \text { Fence or hedge } & .166 & .002 & 1.669 \\ & \text { Outdoor furniture } & .122 & .015 & 1.405\end{array}$

BSA factors also have a positive effect on place attachment. Residents are highly attached to the natural environment (Korpela, Ylén, Tyrväinen \& Silvennoinen, 2009; Muslim, 2016). Many environmental attributes are also critical for place attachment, while natural environment and social communication are more prominent (Kaltenborn \& Williams, 2002), so planting, which could be considered part of the natural environment, and outdoor furniture, 
which encourages social interaction, have an effect on place attachment. The higher the place attachment is for the local residents, the more they like the local landscape (Kaltenborn \& Bjerke, 2002).

\subsection{Scope of impact for the six BSA factors}

The six design factors of the BSA impact the sub-dimensions of the residents' perceptions differently. Among the factors, planting is the strongest and most influential, followed by outdoor furniture, and then by fence or hedge (Table 5). Designers and planners should utilize the three design factors to enhance the effects of environmental amelioration. In addition, directional system and public arts contribute specifically toward the perception of changing, such as positive development and environmental change.

Table 6. Scope of impact of the six design elements on boundary space amelioration

\begin{tabular}{|c|c|c|c|c|c|c|}
\hline & \multicolumn{2}{|c|}{ Perceived change } & \multicolumn{2}{|c|}{ Neighborhood safety } & \multicolumn{2}{|c|}{ Place attachment } \\
\hline & $\begin{array}{l}\text { Positive } \\
\text { development }\end{array}$ & $\begin{array}{l}\text { Environmental } \\
\text { change }\end{array}$ & $\begin{array}{l}\text { Security } \\
\text { against } \\
\text { crime }\end{array}$ & $\begin{array}{l}\text { Traffic } \\
\text { safety }\end{array}$ & $\begin{array}{l}\text { Place } \\
\text { identity }\end{array}$ & $\begin{array}{l}\text { Place } \\
\text { dependence }\end{array}$ \\
\hline $\begin{array}{l}\text { Directional } \\
\text { system and } \\
\text { public arts }\end{array}$ & O & O & O & & & \\
\hline Planting & (0) & O & $\bigcirc$ & $\bigcirc$ & (0) & (0) \\
\hline $\begin{array}{l}\text { Outdoor } \\
\text { furniture }\end{array}$ & O & 0 & & $\bigcirc$ & $\bigcirc$ & O \\
\hline Sidewalk & & & & $\bigcirc$ & & \\
\hline Lighting facilities & & O & & $\bigcirc$ & & \\
\hline Fence or hedge & O & & $\bigcirc$ & & O & $\bigcirc$ \\
\hline
\end{tabular}

\subsection{Limitation}

This study is a cross-sectional investigation, in which the directions of causal inferences are based on literature and theories. Due to financial limitations, only three elementary schools in Tainan were chosen as the study sites for this study. The sample size satisfies the statistical analyses. The result of factor analysis is based on sampling, and different sample site will lead to different result. This study took Taiwan as a study site, the factor of BSA will be different from those in other countries.

\subsection{Conclusion}

The results of this study show that the boundary space amelioration has a significant impact on perceived change, neighborhood safety and place attachment for community residents, and all with large effect size. Upon further study on the effects of various spatial modification factors on the three dimensions, it is revealed that "planting" has the greatest impact on the three dimensions, especially on place attachment (0.39), followed by perception of environmental change (0.36). Except for security against crime, planting has the greatest 
impact on the other five environmental design factors.

Among the elements, planting is the strongest and most influential, followed by outdoor furniture, and then by fence or hedge. Designers and planners should take full advantage of these three design elements to amplify the effect of environmental amelioration. To enhance residents' perception of "positive development", the most effective way is to enhance the planting. Directional systems and public arts especially contribute to the perception of change. Fence or hedge, directional systems, and public arts, and planting are three design factors that have a significant impact on security against crime. To strengthen place attachment, an effective approach is to strengthen planting and vegetation. This study may help designers and planners achieve the desired effects.

Based on the results of the study, it is suggested that special attention be paid to planting and vegetation. Green and beautifying may serve as the guiding principle. The choice of plants should be diversified to beautify the streets. Attention should also be paid to the smell and color of plants, which can relax people. Shrubs serve as demarcation as well as a buffer; trees provide shades, purify the air and absorb noise, which mitigates the negative impacts on the environment. Overall, planting helps people trust the environment, change their perception, and enhance their place attachment. Improvements on fence or hedge provide spatial barrier while increasing people's sense of eliminating blind spots. Such changes are mostly well received, thereby enhancing emotional attachment. The artistic value and interactive nature of outdoor furniture, as well as directional system and public art, can influence people's perceived change and their behaviors.

Planners need to reach out and communicate with the residents in order to construct a recreational corner in the city, revitalize vacant properties, improve the streetscape and bring schools closer to the community. Planners need to interact with the local residents in order to understand how they feel and design the campus boundary space that meets their needs. If security around the campus can be improved, and place attachment can be enhanced, local residents' assessment may be utilized toward bringing school campus closer to the community, where the resources may be shared to build a friendly community.

\section{Acknowledgments}

This research was funded by a grant from the Ministry of Science and Technology Taiwan with the project number: MOST-105-2511-S-006-014

\section{References}

Abdullah, A., Marzbali, M. H., Ramayah, T., Bahauddin, A., \& Tilaki, M. J. M. (2016). Territorial functioning and fear of crime: Testing for mediation in structural equation modeling. Security Journal, 29(3), 461-484.

Anton, C. E., \& Lawrence, C. (2016). The relationship between place attachment, the theory of planned behavior and residents' response to place change. Journal of Environmental Psychology, 47, 145-154.

Bonaiuto, M., Carrus, G., Martorella, H., \& Bonnes, M. (2002). Local identity processes and environmental attitudes in land use changes: The case of natural protected areas. Journal of economic psychology, 23(5), 631-653. 
Bordovskaia, N. V., \& Baeva, I. A. (2015). The psychological safety of the educational environment and the psychological well-being of Russian secondary school pupils and teachers. Psychology in Russia, 8(1), 86.

Clifton, K. J., \& Kreamer-Fults, K. (2007). An examination of the environmental attributes associated with pedestrianvehicular crashes near public schools. Accident Analysis \& Prevention, 39(4), 708-715.

Coeterier, J. F. (1987). De waarneming en waardering van landschappen. Coeterier.

Cohen, J. (1992). A power primer. Psychological bulletin, 112(1), 155.

Daniel, T. C., \& Vining, J. (1983). Methodological issues in the assessment of landscape quality Behavior and the natural environment (pp. 39-84): Springer.

Denes, A. (1993). Notes on eco-logic: Environmental artwork, visual philosophy and global perspective. Leonardo, 387-395.

Devine-Wright, P. (2009). Rethinking NIMBYism: The role of place attachment and place identity in explaining place-protective action. Journal of community \& applied social psychology, 19(6), 426-441.

Grahn, P., \& Stigsdotter, U. K. (2010). The relation between perceived sensory dimensions of urban green space and stress restoration. Landscape and Urban Planning, 94(3-4), 264-275.

Hair, J. F. (2010). Black, WC, Babin, BJ, \& Anderson, RE (2010). Multivariate data analysis, 7.

Herzog, T. R., Herbert, E. J., Kaplan, R., \& Crooks, C. (2000). Cultural and developmental comparisons of landscape perceptions and preferences. Environment and Behavior, 32(3), 323-346.

Hong, J., \& Chen, C. (2014). The role of the built environment on perceived safety from crime and walking: examining direct and indirect impacts. Transportation, 41(6), 1171-1185.

Jessor, R., \& Jessor, S. L. (1973). The perceived environment in behavioral science: Some conceptual issues and some illustrative data. American Behavioral Scientist, 16(6), 801-828.

Kaltenborn, B. P., \& Bjerke, T. (2002). Associations between landscape preferences and place attachment: a study in Røros, Southern Norway. Landscape Research, 27(4), 381-396.

Kaltenborn, B. P., \& Williams, D. R. (2002). The meaning of place: Attachments to Femundsmarka National Park, Norway, among tourists and locals. Norsk Geografisk Tidsskrift, 56(3), 189-198.

Kasarda, J. D., \& Janowitz, M. (1974). Community attachment in mass society. American sociological review, 328339.

Korpela, K. M., Ylén, M., Tyrväinen, L., \& Silvennoinen, H. (2009). Stability of self-reported favourite places and place attachment over a 10-month period. Journal of Environmental Psychology, 29(1), 95-100.

LaScala, E. A., Johnson, F. W., \& Gruenewald, P. J. (2001). Neighborhood characteristics of alcohol-related pedestrian injury collisions: a geostatistical analysis. Prevention Science, 2(2), 123-134.

Lau, S. S. Y., Gou, Z., \& Liu, Y. (2014). Healthy campus by open space design: Approaches and guidelines. Frontiers of Architectural Research, 3(4), 452-467. 
Heng, Z., et.al. / Asian Journal of Quality of Life (AjQoL), 4(16) May/Aug 2019 (pp.16-32)

Lewicka, M. (2013). Localism and Activity as two dimensions of people-place bonding: The role of cultural capital. Journal of Environmental Psychology, 36, 43-53.

Lin, C.C., \& Lockwood, M. (2014). Forms and sources of place attachment: Evidence from two protected areas. Geoforum, 53, 74-81.

Lindsay, P. H., \& Norman, D. A. (2013). Human information processing: An introduction to psychology: Academic press.

Low, S. M., \& Altman, I. (1992). Place attachment Place attachment (pp. 1-12): Springer.

Lynch, K., \& Hack, G. (1984). Site planning: MIT press.

Matilainen, A., Pohja-Mykrä, M., Lähdesmäki, M., \& Kurki, S. (2017). "I feel it is mine!"-Psychological ownership in relation to natural resources. Journal of Environmental Psychology, 51, 31-45.

Mehta, V. (2014). Evaluating public space. Journal of Urban Design, 19(1), 53-88.

Moore, R. L., \& Graefe, A. R. (1994). Attachments to recreation settings: The case of rail-trail users. Leisure sciences, 16(1), 17-31.

Muslim, Z. (2016). Design Transformation based on Nature and Identity Formation in the Design of Landscape Elements. Environment-Behaviour Proceedings Journal, 1(1), 189-196.

Ode, Å., Fry, G., Tveit, M. S., Messager, P., \& Miller, D. (2009). Indicators of perceived naturalness as drivers of landscape preference. Journal of Environmental Management, 90(1), 375-383.

Omar, D., Omar, K. A., Othman, S., \& Yusoff, Z. M. (2016). Walkability design for urban public housing park. Environment-Behaviour Proceedings Journal, 1(3), 311-317.

Pikora, T., Giles-Corti, B., Bull, F., Jamrozik, K., \& Donovan, R. (2003). Developing a framework for assessment of the environmental determinants of walking and cycling. Social science \& medicine, 56(8), 1693-1703.

Purcell, A. T., \& Lamb, R. J. (1998). Preference and naturalness: An ecological approach. Landscape and Urban Planning, 42(1), 57-66.

Rapoport, A. (2016). Human aspects of urban form: towards a man-environment approach to urban form and design: Elsevier.

Riley, R. B. (1992). Attachment to the ordinary landscape Place attachment (pp. 13-35): Springer.

Ruihai, Z., \& Dinghai, Y. (2017). Analysis and reform strategies of campus landscape of Hainan University. Journal of Landscape Research, 9(2), 23.

Saeidi, S., Mohammadzadeh, M., Salmanmahiny, A., \& Mirkarimi, S. H. (2017). Performance evaluation of multiple methods for landscape aesthetic suitability mapping: A comparative study between Multi-Criteria Evaluation, Logistic Regression and Multi-Layer Perceptron neural network. Land Use Policy, 67, 1-12.

Saelens, B. E., Sallis, J. F., Black, J. B., \& Chen, D. (2003). Neighborhood-based differences in physical activity: an environment scale evaluation. American journal of public health, 93(9), 1552-1558.

Scannell, L., \& Gifford, R. (2017). The experienced psychological benefits of place attachment. Journal of Environmental Psychology, 51, 256-269. 
Sell, J. L., \& Zube, E. H. (1986). Perception of and response to environmental change. Journal of architectural and planning research, 33-54.

Strumse, E. (1996). Demographic differences in the visual preferences for agrarian landscapes in western Norway. Journal of Environmental Psychology, 16(1), 17-31.

Sullivan, W. C., Kuo, F. E., \& Depooter, S. F. (2004). The fruit of urban nature: Vital neighborhood spaces. Environment and Behavior, 36(5), 678-700.

Toruńczyk-Ruiz, S., \& Lewicka, M. (2016). Perceived social diversity and neighbourhood attachment: The role of intergroup ties and affective appraisals of the environment. Evidence from Poland. European Journal of Social Psychology, 46(7), 818-832.

Tuan, Y.-F. (1975). Place: an experiential perspective. Geographical review, 151-165.

Van Treese II, J. W., Koeser, A. K., Fitzpatrick, G. E., Olexa, M. T., \& Allen, E. J. (2017). A review of the impact of roadway vegetation on drivers' health and well-being and the risks associated with single-vehicle crashes. Arboricultural Journal, 39(3), 179-193.

von Wirth, T., Grêt-Regamey, A., Moser, C., \& Stauffacher, M. (2016). Exploring the influence of perceived urban change on residents' place attachment. Journal of Environmental Psychology, 46, 67-82.

Williams, D. R., \& Roggenbuck, J. W. (1989). Measuring place attachment: Some preliminary results. Paper presented at the Abstracts: 1989 leisure research symposium.

Wolf, K. L. (2003). Freeway roadside management: the urban forest beyond the white line. Journal of Arboriculture, 29(3), 127-136.

Wood, L., Shannon, T., Bulsara, M., Pikora, T., McCormack, G., \& Giles-Corti, B. (2008). The anatomy of the safe and social suburb: an exploratory study of the built environment, social capital and residents' perceptions of safety. Health \& place, 14(1), 15-31.

Yu, K. (1995). Cultural variations in landscape preference: comparisons among Chinese sub-groups and Western design experts. Landscape and Urban Planning, 32(2), 107-126.

Zhang, H., \& Lin, S.-H. (2011). Affective appraisal of residents and visual elements in the neighborhood: A case study in an established suburban community. Landscape and Urban Planning, 101(1), 11-21. 